\title{
What Matters Most? The Power of Kafka's Metamorphosis to Advance Understandings of HIV Stigma and Inform Empathy in Medical Health Education
}

\section{Courtenay Sprague ${ }^{1}$}

Published online: 21 February 2022

(c) The Author(s), under exclusive licence to Springer Science+Business Media, LLC, part of Springer Nature 2022

\begin{abstract}
HIV stigma, a social-medical problem, continues to confound researchers and health professionals, while undermining outcomes. Empathy may reduce stigma; its absence may predict stigma. This research investigates: How does Kafka's Metamorphosis advance understandings of HIV stigma in medical health education? Metamorphosis amplifies the sociological-relational mechanisms fostering HIV stigma. It offers a multi-disciplinary, responsive space for ethical, humanistic and clinical inquiry to meet: enabling students to consider how social structures shape health inequities, moral, social experience, and their professional identity within. Metamorphosis may ultimately promote medical health humanities' social mission-allowing literature to unfold such revelations towards greater equity in health.
\end{abstract}

Keywords Stigma $\cdot$ HIV and AIDS · Empathy $\cdot$ Social determinants of health $\cdot$ Medical health education

\section{Introduction}

Stigma presents a perplexing problem for medicine and society. While stigma is a social construct, it remains a significant contributor to morbidity and mortality, globally (Hatzenbuehler, Phelan, and Link 2013). Stigma's deleterious health effects are likely even underestimated, since numerous health conditions and disorders are stigmatized, from disabilities to mental health and substance use disorders (Pachankis et al. 2018; Remien et al. 2019). Broadly defined as a "mark of disgrace associated with a particular circumstance, quality, or person" (Oxford English Dictionary 2021), stigma functions by affixing a negative label to individuals as a result of their condition, disease, or membership within a marginalized community-effectively "spoiling" their social identity (Goffman 1963, 5). Foundational theories of stigma are rooted in the work of early sociologists and philosophers who sought to make sense of social exclusion in relation to power and culture

Courtenay Sprague

courtenay.sprague@umb.edu

1 University of Massachusetts Boston, Boston, MA, USA 
(Goffman 1963; Bourdieu 1977; Foucault 1995). Conceptualizations have since evolved to embrace the role of structural inequalities and other mechanisms that foster stigmatization in social context (Crocker, Major, and Steele 1998; Link and Phelan 2001; Parker and Aggleton 2003; Pantelic, Sprague, and Stangl 2019). Yet, despite increased theoretical and practical understanding from different fields, stigma continues to confound researchers and professionals (Geter, Herron, and Sutton 2018). Indeed, stigma remains persistent and pervasive, generating adverse mental and physical health consequences for people, globally-especially for those living with the human immunodeficiency virus (HIV) (Rao et al. 2019; UNAIDS 2020a).

HIV, and its end-stage, acquired immunodeficiency syndrome (AIDS), continue to live large in the global public imagination. HIV differentiates itself from other stigmatized conditions as an infectious disease: one contracted primarily through sex. HIV has no cure, not even a vaccine. HIV and AIDS have long been associated with shame, secrecy, and death across settings (Shilts 1987; Power 2003). In US social-cultural context, HIV-related opportunistic infections were visibly prominent among gay men in the epidemic's early years. Ugly lesions, angry rashes or wasting were hallmarks of illness provoking alarm, dread and discrimination against those living with the virus, while infringing their human rights and dignity (Sontag 1989; Gruskin, Mills and Tarantola 2007).

The year 2021 marked forty years of a global HIV epidemic that has claimed more than thirty-six million lives to date (UNAIDS 2020b). Over these decades, people living with HIV have experienced well-documented stigma, but especially racial, ethnic, sexual and gender minorities, sex workers, users of substances-and women. These key populations may also experience intersectional stigma associated with being sexual, racial, ethnic or gender minorities and/or other negative social identifiers, e.g., histories of violent victimization (Turan et al. 2019; UNAIDS 2020a). Important treatment advances have extended life expectancy and references to a so-called 'end of AIDS' are made (see Walker 2020; Tsampiras 2020). Yet stigma thwarts this policy goal at global and national levels. HIV stigma undermines biomedical advances in treatment and prevention across the entire HIV care continuum by reducing people's access to HIV testing, care, onward adherence, and viral suppression (Logie et al. 2018; Rueda et al. 2016). Among one hundred persons living with HIV in the US today - a high-income country - just fifty are retained in care and only fifty-six achieve viral suppression (US Centers for Disease Control and Prevention 2020a-b). HIV stigma also erodes family and social support, with pernicious negative mental health consequences, from depression and anxiety to diminished self-worth (Remien et al 2019; Orza et al. 2015).

\section{Social determinants of health}

Unraveling stigma's layers of complexity requires recognizing that, unlike biological or genetic factors that are not easily modified, stigma, a social determinant of health (SDH), is produced by societies and individuals, and thus, changeable. SDH, "the circumstances in which people live, grow, work and age (WHO 2008, 1), negatively influence health including lack of access to secure employment and education, absence of social, financial protection, and housing and policies that criminalize social groups, such as sexual and gender minorities (Solar and Irwin 2010; UNAIDS 2020a). Importantly, SDH, like stigma, compound existing social and economic disadvantage for excluded groups who are typically already at higher risk of exposure to disease due to environmental and social factors. Hence 
SDH further magnify the social and economic consequences of ill health for vulnerable populations (see Diderichsen, Evans, and Whitehead 2001, Figure 1, 15). SDH are responsible for most health inequities (Solar and Irwin 2010; see Anand, Peter and Sen 2004). It doesn't have to be this way. Since health inequities are underpinned by social causes, by definition, they are viewed as avoidable, unfair, unjust, and capable of being altered, through evidence-informed, long-term policies and interventions (WHO 2013; Braveman and Gruskin 2003).

\section{Knowledge gaps}

The extant stigma literature is rich, multi-disciplinary, and evolving. Scholars have, however, highlighted particular gaps, including two relevant to this work. First, stigma researchers, especially in North America and Europe, have overlooked its moral, cultural dimensions (Yang et al. 2007). In settings like the Southern United States, HIV stigma can be fully stitched into the social fabric in ways that are not fully appreciated. In Mississippi, the state with the highest HIV-related mortality and poverty rates among all states (Reif et al. 2019), one man with HIV portrayed the stigma that was typically enacted by others:

$[\mathrm{H}]$ ere in the state of Mississippi if a person knew that you were [HIV] positive, of course they're gonna feel some type of way, you know?...They gonna be like, 'Don't sit next to him or don't drink by him or eat by him, or ... don't let my kids play with him'(Sprague et al. 2019, 8).

As this participant conveys, stigma bars individuals with HIV from taking part in activities that hold social meaning across cultures such as eating with family and friends. These

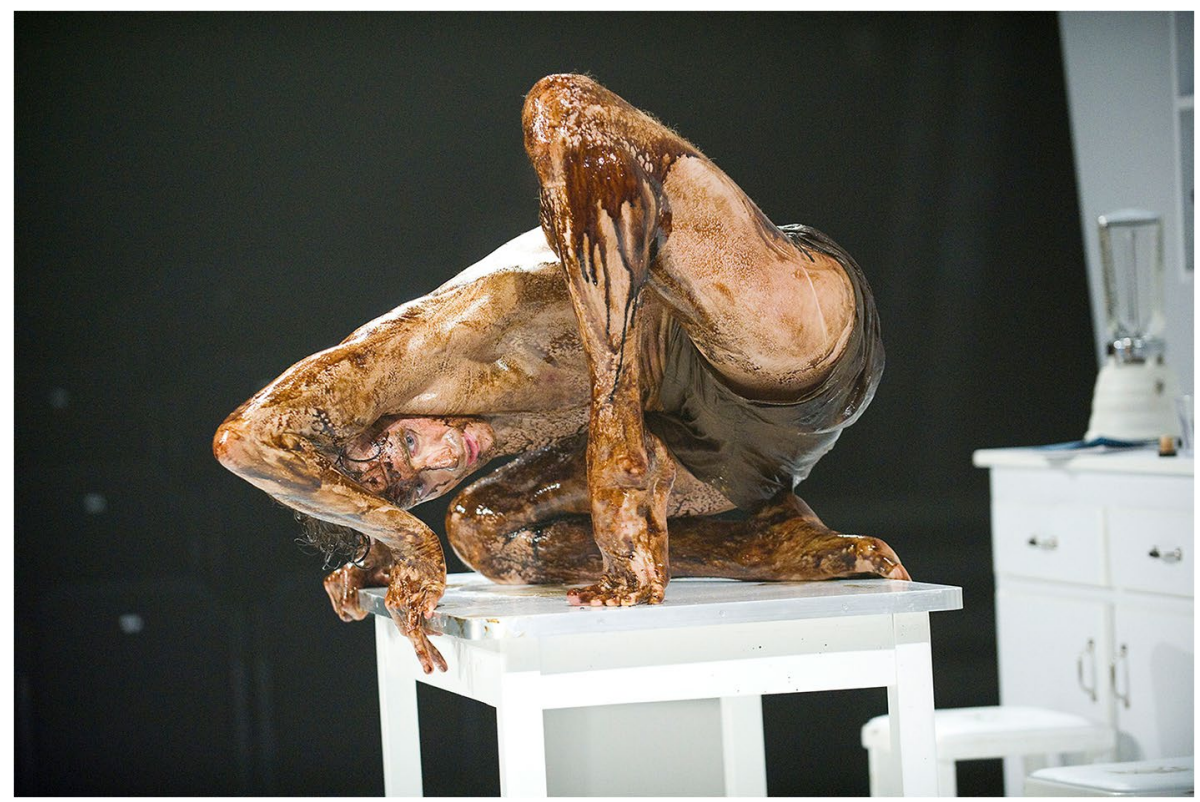

Fig. 1 A scene from Metamorphosis at the Linbury Studio, Royal Opera House, London, 2011. Published with the permission of The Guardian/Tristram Kenton/eyevine/Redux 
"everyday" human interactions_-cherished rituals_-"matter greatly" as Kleinman stresses (2004, 269-270). Indeed, they form the foundation of our local, social worlds. The value we all place on such every day encounters became magnified during the coronavirus-19 (COVID-19) lockdowns. Similarly, the isolation and loneliness generated by stigma corrodes moral, social experience for those living with HIV, including "what matters most": love, connection, being and doing what one values and desires (Yang et al. 2007, 524). Stigma ultimately threatens the ability of individuals to construct lives they have reason to value, undercutting their human development and capabilities (Sen 1999).

In a second lacuna, researchers have cited the need to investigate how HIV stigma is embedded in healthcare settings by considering attitudes and behaviors of HIV physicians who have a therapeutic alliance with their patients (Geter, Herron, and Sutton 2018; Weiss et al. 2017; Hoffart et al. 2012). In one qualitative study we conducted to understand why people in Alabama delay or lapse antiretroviral therapy, a participant living with HIV stated he had switched doctors because "the other doctor wouldn't touch me. He wouldn't touch my body" (Sprague and Simon 2014, 9). In generalized epidemics in Southern African countries, public adverts, television and workplace programs routinely prompt individuals to know their HIV status-making HIV information publicly accessible (George and Sprague 2011; South African National AIDS Council 2017). In contrast, in concentrated HIV epidemics like in the United States and Canada, HIV guidance typically comes from specialist providers: placing emphasis on the relationship of trust forged between a person living with HIV and a physician or nurse. HIV stigma, when experienced by patients during the clinical encounter, can have inestimable, detrimental consequences, since individuals must maintain continuous HIV care throughout their lives (Geter, Herron, and Sutton 2018; Reif et al. 2019).

An uncharacteristically blunt press release by the US Centers for Disease Control and Prevention underscored the continuing high burden of HIV among black and Latino sexual minority men in 2016: "If current HIV diagnoses rates persist, about 1 in 2 black men who have sex with men (MSM) and 1 in 4 Latino MSM in the United States will be diagnosed with HIV during their lifetime" (1). These data imply that unless there are concerted efforts to arrest new HIV infections among black and Latino MSM, high incidence and pronounced race- and ethnicity-based HIV-associated inequities will continue, even as physicians and nurses continue to treat HIV in their patients.

In US clinical settings, factors associated with stigmatizing attitudes, beliefs and behaviors towards those with HIV were gender, race, religion, and provider category: stigma was found primarily among white, male, primary care physicians and clinical providers with no or limited HIV stigma training in the past twelve months-emphasizing a role for greater HIV education and training among providers and health professionals in training (Geter, Herron, and Sutton 2018; Frain 2017). Systematic reviews also underscore the need for greater attention to sexual health and sexual and gender minority health in the curriculum of student health professionals. A review of clinical education in the US found that $44 \%$ of all medical schools "may have no formal curriculum in sexual health at all" (Rubin et al. 2018, 1415).

Notably, US physicians and nurses in training represent a new generation of leaders in the medical health professions who will, in turn, shape the institutional cultures, norms and practices of health settings and staff. In recent years, divisive socio-political discourse and growing social inequalities have increasingly been documented, globally (World Economic Forum 2017). In the US, social divisions reached a fever pitch 
in 2020, following the shocking killing of George Floyd, an unarmed black man, at the hands of police. At the same time, race-based health inequities-long evident for those with HIV-were pushed to the foreground during the COVID-19 pandemic (Egede and Walker 2020). Health and clinical settings mirror social settings. Adverse social attitudes and norms can be reinforced or contradicted by individuals in health facilities (Hay et al. 2019). The need for educational curricula responsive to health inequities and social justice is therefore crucial: hence the focus on this cadre and health settings as a location of intervention vis-à-vis HIV stigma. If stigma is socially produced by individuals and modifiable, then it is crucial to ascertain: what types of interventions and educational curricula, including literature, are effective at advancing greater understandings of HIV stigma in health settings?

\section{The role of empathy in HIV stigma}

One pathway to address and reduce stigma may be through empathy. Some studies indicate that a lack of empathy may predict HIV stigma; and conversely, empathy may reduce HIV stigma (Nyblade et al. 2020; Batey et al. 2016; Lin et al. 2012). Notably, there is no consensus on definitions for empathy in the literature; it is a subtle, complex construct to operationalize with many studies relying on self-reports-posing challenges to the validity of research on empathy (Kelm et al. 2014; Batt-Rawden et al. 2013). With those provisos, many researchers increasingly agree that empathy is an umbrella term having at least three components, one I adopt here (Weisz and Cikara 2020).

First, empathy has an affective aspect, also called experience sharing, where people feel the states of others, vicariously, though not to the same degree. Second, there is a cognitive component associated with empathy, called theory of mind or perspectivetaking, where individuals are able to consider the experiences and thoughts of others. Third, the motivational component of empathy, often characterized as compassion, reflects prosocial behaviors that prompt people to reduce the suffering of others, including strangers (Weisz and Cikara 2020). Warranting emphasis in the debates about empathy is this: empathy is an engine for prosocial goals. The three components of empathy are associated with higher relationship satisfaction, better health, increased emotional wellbeing, caring for children, coordinated action toward group goals, better team performance, higher employee satisfaction, and higher occupational commitment (Weisz and Cikara 2020). But empathy has its limits. Studies are mixed but research indicates that empathy declines during medical training and residency, as physicians begin routine patient care (Thirioux, Birault, and Jaafari 2016; Chen et al. 2012; Neumann et al. 2011). ${ }^{1}$

Of significance, alongside ongoing debates about empathy, the Association of American Medical College guidelines continue to locate empathy at the center of its expectations of physicians, stating: "Physicians must be compassionate and empathetic in caring for patients, and must be trustworthy and truthful in all of their professional dealings" $(1998,4)$. Training in empathy for health professionals and students has been found to be efficacious in a meta-analysis of nineteen randomized controlled trials (Teding van Berkhout and Malouff 2016). Systematic reviews continue to document the importance of empathy for patient care and outcomes. Moreover, provider empathy has been associated 
with reduced patient anxiety (Weiss et al. 2017); higher medication self-efficacy among patients (Cohn, Moore, and Beach 2016); and-despite the absence of consistent outcome measures-even clinical outcomes (Kelm et al. 2014); one systematic review concluded: "empathy delivers significantly better clinical outcomes" (Derksen, Bensing, and LagroJanssen 2013, e76).

Markedly, findings among patients with HIV similarly underscore the role of provider empathy (Flickinger et al. 2016). Patient satisfaction with care has been associated with improved HIV care retention, adherence and outcomes (measured as viral suppression) in studies conducted in high-income countries (Dang et al. 2012). In systematic reviews, the most important aspect of health care for those with HIV (signifying satisfaction) was the patient-provider relationship, encompassing: trust, empathy, professionalism, provision of emotional support-and notably — taking an interest in patients' personal relationships and comfort discussing personal issues (Cooper et al. 2016). Moreover, in some studies, the patient-provider relationship far exceeded other factors (Dang et al. 2012).

To underscore the point: those living with HIV, often part of socially marginalized or devalued groups, face numerous obstacles to achieving optimal HIV outcomes, with stigma compromising care and wellbeing (US Centers for Disease Control and Prevention 2020ab; Reif et al. 2019). The evidence indicates people living with HIV value, not only quality of care, but the quality of relationship with their providers: those who demonstrate empathy and show interest in their lives, including social determinants that influence their opportunities to be healthy and to engage in 'what matters most' (Yang et al. 2007, 524; Okoro and Odedina 2017). In understanding the complexities of HIV stigma, both the problem and response, it is necessary to ask: if stigma precludes optimal HIV outcomes and wellbeing, are stigma reduction interventions, including educational curricula, effective in overturning or reducing stigma in health settings?

\section{Stigma reduction interventions, empathy and their effectiveness}

The evidence indicates that interventions to curb HIV stigma and discrimination have been found to be effective in health and other settings (e.g., education, workplace, community). Interventions are a cluster of structured activities aimed at achieving change at specific levels, with identified outcomes and measures. In the context of HIV-related stigma, structural approaches are necessary and they encompass activities to reduce or abolish the structural factors that influence stigma at differing levels, including laws and policies that institutionalize unfair treatment or discrimination of people with HIV (Stangl et al. 2013). Taken together, this comprises a whole of society approach that works upstream to engage with social-economic structures and downstream to provide HIV treatment, prevention, care and support, while ensuring human rights and dignity in health settings. As part of this approach, the clinic thus needs to be seen as one location, or sphere of intervention, among overlapping spheres (countries with generalized HIV epidemics employ this approach through their multi-stakeholder national strategic plans, see South African National AIDS Council 2017).

In 2020, UNAIDS documented twenty effective interventions to reduce HIV-related stigma and discrimination in healthcare settings, including training student physicians and nurses across low-and-lower-income (Ghana and Tanzania), upper middle-income (South Africa) and high-income settings (Canada, the US and China) (see UNAIDS 2020a, Annex 4, 75-76; Nyblade et al. 2020; Batey et al. 2016; Li et al. 2013; Lin et al. 2012). Strikingly, 
empathy building was rooted within the intervention approach and methods. For example: "Participatory trainings of facility staff use discussion and self-reflection to build empathy and reduce distance (contact strategies)" (Nyblade et al. 2020, S96). In another, empathy was measured using the Jefferson Scale of Physician Empathy (Lin et al. 2012; Hojat et al. 2002). In a third, measures for provider participants included empathy, HIV knowledge, and perceived risk (Batey et al. 2016, 521). These HIV-related interventions aimed to do more than cultivate empathy, however. They sought to increase knowledge, inform the beliefs and attitudes of health professionals, and change the culture of health facilities (Nyblade et al. 2020). Factors identified as essential components of the interventions' effectiveness were: multi-methods; reliance on participatory approaches, including participatory training; institutional support and leadership (including budgeting); and, especially, contact with and discussions of participants with those living with HIV (see Batey et al. 2016; Nyblade et al 2020).

These stigma reduction interventions made no mention of literature or the arts (UNAIDS 2020a). Nonetheless, in medical training curricula, educators and scholars have long-viewed art, literary texts, and narrative as pedagogical tools that enable readers to "gain empathy and compassion for human suffering," among other functions (Kottow and Kottow 2002, 41; Krishnasamy et al. 2019; McDonald et al. 2015; see Hunter 1991). Indeed, the recognition of the literature-health-medicine nexus, and the role of literature to inform readers' understandings of health and ill health, remains a cornerstone of the medical health humanities (see Jones, Wear and Friedman 2018, 1-9; also Whitehead et al. 2016. For other seminal perspectives on the role/s of literature in medical health education, see Jones 1999; Evans 2003; Hawkins and McEntyre 2000; for the role of the arts in medicine, see Scott 2000.) The medical/health humanities have engaged with HIV and AIDS over the years in crucially important ways that have illuminated and reshaped knowledge and understanding of key constructs, relationships and concerns (O'Connell 2020; Hutchinson and Dhairyawan 2017; Tomso 2010; Farmer 2001; Hawkins and McEntyre 2000). Some of the most explicit discussion of the role of the medical health humanities and HIV, as well as themes related to social constructions of illness, have emerged most recently from South Africa (Tsampiras 2020; Pentecost et al. 2018; Reid 2014). Performative theatre, plays, and art have also been mobilized to powerfully depict the experience of those living with the virus (see Jones 1994). In this way, stories, art and film have long been used to "enhance empathy, perspective-taking, and openness to otherness" both in medical education curricula (Kumagai and Wear 2014, 973) — and in the case of HIV-to deepen public awareness.

There are robust, wide-ranging and persistent debates about empathy among intersecting literatures, spanning: the challenge of achieving "sustainable empathy" in patient care and outcomes (see Zaki 2020, 459); factors associated with empathy's decline among providers (Chen et al. 2012; Thirioux, Birault, and Jaafari 2016); interventions to cultivate empathy in medical health curricula among both physicians (Kelm et al. 2014) and students, including use of narrative medicine and literature to increase empathy (with differing results) (Krishnasamy et al. 2019; Patel et al. 2019; McDonald et al. 2015; Yang and Yang 2013). There is also a critical literature on empathy from the perspective of medical health humanities (see Garden 2007), including a recurring critique that the burden to build empathy should not be thrust onto the shoulders of the medical health humanities (for discussion, see Jones, Wear, and Friedman 2018, 1-4). Additionally, some have stressed empathy's role in leading to more ethical health care and enhanced wellbeing for physicians themselves (Kelm et al. 2014). 
On their own, arts and literature would not be sufficient to serve as anti-stigma interventions targeting HIV stigma at the structural level. They continue to play a crucial role in medical health education, however, and when combined with other intervention activities, may influence participants in profound ways (Marchalik and Jurecic 2015; Hawkins and McEntyre 2000). Literature can be part of larger efforts within medical health education curricula to overturn health inequities and inform student understandings of social forces and determinants that shape people's health behaviors, constraints, and opportunities to be healthy. Growing empirical research has found that reading narrative fiction affects our emotions prior, while, and after reading, shaping our experiences in powerful ways. Once evoked, our emotions affect our experience of the narrative, influencing our cognitive processing in ways that may "prime" our experience in the real world (Mar et al. 2011) - thus also creating the conditions for exploring the intersection of social-structural factors, including class, race, gender, income, and identity. Increasing experimental evidence indicates that reading literary fiction enhances theory of mind tasks associated with empathy (Kidd and Castano 2013). To add to the impetus, in 2018, the US Board on Higher Education and Workforce of the National Academies of Sciences, Engineering and Medicine conducted a study that reviewed the evidence underpinning the assumption that educational programs that "mutually integrate learning experiences in the humanities and arts with science, technology, engineering, math, and medicine (STEMM) lead to improved educational and career outcomes for undergraduate and graduate students" (2018, xii). The committee found sufficient compelling evidence to recommend this integration, stating that: "further effort be expeditiously exerted to develop and disseminate a variety of approaches to integrated education" (xii). Such an integration of STEMM, arts and humanities requires embracing a pedagogical shift in valuing knowledge from the medical health humanities, and in the materials and methods used to inform student learning. What materials may enhance greater critical discussion and understandings of HIV stigma's sociological processes among students in the medical health sciences, including reflection on the role of empathy and its absence towards those who experience HIV stigma?

Enter Kafka In 2016, as part of an academic residency, I was writing up findings from empirical HIV research on women in South Africa, a principal focus of my work as a social health scientist for over fifteen years. The corrosive mental and physical health effects of stigma in this population, like other populations elsewhere, were clear (Sprague 2018; Orza et al. 2015). Yet stigma's power still seemed to escape full expression, including in my teaching of students in the health sciences. Accustomed to reading literature in the evenings, I spied a book in the Bellagio Center's well-stocked library I had long wanted to read. That slim volume, Kafka's Metamorphosis, even seemed to whisper, 'choose me.' I devoured it that night. One of the acclaimed works of the $20^{\text {th }}$ century (Strauss 2016), Kafka's compact forty-seven-page novella seemed to convey a more effective depiction of stigma than any academic research I had read or generated, sparking this inquiry. I investigated: how might Kafka's Metamorphosis reveal greater insight into the process and experience of HIV stigma? And what are the implications for medical health education, if any?

Before presenting the original themes derived from my analysis, I foreground selected, primary themes from the extant literature, briefly highlighting (a) Kafka's background and its influence on Metamorphosis, followed by (b) scholars' reading of the text, particularly its (c) use in medical health education, with emphasis on dominant concerns and gaps. 


\section{Kafka's metamorphosis in the medical health humanities}

Set in Prague and published in 1915, Metamorphosis confounded critics then, as today (Cronenberg 2014). Our protagonist, Gregor Samsa, wakes up in his bed at the start of a new day, having been converted into a giant 'bug' (wanze in German) during the night. Gregor is a traveling salesman, and the family, middle class (Kafka 2016, 3, 22, footnote 4). Attention to Metamorphosis, Kafka's brief "masterpiece" and his other works, reflect the recognition by scholars, whether of political and social criticism, religion, philosophy, psychiatry or literature, that Kafka's work is "inexhaustible," (Strauss 2016, 129). Numerous scholars, studying Metamorphosis, "have tried to get at its heart and soul, only to be followed by others, similarly dedicated and agile, yet anxious to recommend a quite different angle" Coles remarks (1995, 306-307). Hence, Cole counsels: "There is no point trying to figure out the explanation for this...powerfully affecting story" (306). One can almost hear Kafka laughing in the distance as I tap out this sentence.

Kafka's works plumbed themes that were reflected in his own life (1883-1924) and social world (Strauss 2016). Metamorphosis can be read as a satire on the stifling aspects of a conventional, capitalistic life (Rowe 2002). Kafka lived this life: making his earnings as a lawyer by day, while writing diligently, even obsessively, by night (Pohland 2000). During Kafka's time, German cultural values were shifting toward conformity with authoritarianism, as images of honor, strength, and virility came to define "civic virtue and social value" (Pohland 2000, 234). Within this historical period, theories of eugenics, social Darwinism, authoritarian hygiene and control of disease were taking hold (Pohland 2000). Importantly, these ideas were infusing Kafka's views towards disease in his writing. Through illness and otherness, Kafka's texts probe understandings of self that fail to conform with the rational, scientific order of the day, but rather "transgresses" those understandings, emphasizes Pohland (2000, 233). This includes Kafka's treatment of tuberculosis (TB) even before he contracted it. At the time, TB, or consumption, altered - from being viewed as "a signature of heightened spirit, sexuality, and individualization, even genius- to instead become increasingly stigmatized" (Pohland 2000, 234). TB would eventually claim Kafka's life when he was just forty-one.

Kafka was also plagued by depression and anxiety (Abbasian 2007), references to which punctuate his letters. Writing to fiancée, Felice (they never married), while drafting Metamorphosis, Kafka reveals his struggles to write, penning his feelings about the story and protagonist Gregor: "a short story...occurred to me in bed in my misery, and now troubles me and demands to be written" $(2016,52)$. Continuing to refer to his 'misery' in his letter to Felice (dated November 17-18, 1912), Kafka bemoans his battle to write Metamorphosis: "Not a line of the novel has been written today and I go to bed tonight with little enthusiasm" (52).

Kafka expresses his feelings for Felice, his depression and his protagonist's sad plight:

Dearest, oh God, how I love you! It is very late at night. I have put aside my little story...it is a little frightening. It is called Metamorphosis....I am thoroughly depressed at the moment, and perhaps I shouldn't be writing at all. But my hero's story has also had a very bad time today, and yet it is only the last lap in his misfortune, which is now becoming permanent. (53) 
That Metamorphosis has become a core text in medical/health humanities education for more than four decades can be attributed in part to its salience as a teaching tool (Flood and Soricelli 2018; Kumagai and Wear 2014). This salience is multi-faceted. Central to its appeal as a text for medical practitioners seeking to better understand their patients - and themselves who might eventually become patients-stress Taran and Detsky, lies in the novella's ability to mimic all of the uncertainty of illness. Gregor:

is a stranger to the very process that undoes him. Similarly, for patients, living with disease may be... a battle where the enemy's next move can never be predicted. Disease therefore remains for most people a shape-shifting foe. (Taran and Detsky 2018, 753)

Scholars have written, too, that the work is able to nimbly capture the signal experiences of neglect, dehumanization, ambiguity, and of seeking meaning through illness and suffering (Flood and Soricelli 2018; Kumagai and Wear 2014). Strikingly, some of this suffering is created by social norms and expectations. Even prior to his conversion into a large insect, Gregor has become alienated from his essential self through his soul-thrashing occupation (Flood and Soricelli 2018). Gregor is a salesman operating in an utterly exhausting profession but what Gregor has actually sold is himself, as Bernofsky notes (quoted in Kafka 2016, xvii).

In Metamorphosis, Kafka invites an examination of the purpose of life, Coles (1995) emphasizes. Rowe presses the point, stressing what he sees as Kafka's sweeping intent: Metamorphosis also carries a warning message for humanity, one particularly appropriate for medical practitioners. Rowe cautions: "It represents a challenge to the notion of a shared humanity and solidarity that accepts an obligation to protect its most vulnerable members, including those with life-threatening illness" $(2002,278)$.

In addition to the vulnerable among us, Kafka asks us to consider the status quo, the price of alienation-not only Gregor's transformation into death, but as his family represents, our continuing experience as survivors. In other words, "do we profit handily from the human degradation of others?" as Coles puts the question (1995, 310-311). While some writers argue that Kafka's text evinces a grim view of humanity, others like Rowe view the work differently (see also Evans 2003; Abbasian 2007). He writes: "Our humanity is not a given. It can wear away. We maintain it by drawing on structures that nourish it and undertaking conscious efforts that may help to keep the milk of human kindness flowing" (2002, 279).

In this manner, again, the novella forces each of us to take a long look at ourselves "at what we are and what we might become" Coles writes $(1995,311)$. Kumagai and Wear observe, in this manner, literature and the arts play a crucial function of troubling one's assumptions, to view the self and the world in fresh light (2014). The resulting 'estrangement' (a term employed by Russian author Viktor Shlovsky, who used it to refer to the structure of narrative) can create a disruption that allows for dialogue on biases, while also breaking open the opportunity for bearing witness, the authors stress (Kumagai and Wear 2014).

Strikingly, while some work explores different stigma types in Metamorphosis, such as the stigma of mental illness, as well as alienation and neglect (Abbasian 2007; Antony 2017; Pohland 2000; Kumagai and Wear 2014; Flood and Soricelli 2018), I could find no work that analyzes the relevance of Metamorphosis to HIV stigma in any detail. This work is situated within that aperture. 


\section{Themes}

In Act I, Kafka lays the essential groundwork to establish the plot line and accompanying themes that unspool over the story's course. Two primary themes resulted from the analysis of the textual data: What is at stake and stigma as an intersubjective process. I present the story as a five-act play, to categorize the drama as Kafka tells it.

\section{Act I. The change}

Gregor Samsa awakens in the early morning, having been transformed into a large insect during the night. Gregor's household includes his father, mother and seventeen-year old sister, Grete (Kafka 2016, 3, 22, footnote 4).

\section{Theme 1. What is at stake}

Stigma as a social process begins unfolding in Gregor's household following Gregor's transformation into an insect. Alongside his physical change into a beetle, Gregor's valued identity within the social hierarchy will soon be lost. Gregor is the family's sole breadwinner: a role he cherishes. Kafka makes it clear that Gregor had stepped in to occupy the role of economic provider, after his aging father's ability to work had been compromised: "Gregor's father...was old and hadn't worked in a full five years,...he was supposed to avoid overtaking himself”' (23).

As the story opens, the centerpiece of the drama hinges on the threat of a new financial crisis engulfing Gregor's family. Avoiding this cataclysm is Gregor's chief aim. It underpins the urgency of Gregor's need to get out of bed and catch his train to work. Problematically, however, when Gregor awakens encased in the shell of an insect in the wee hours of the morning, his legs have become like a millipede's. Despite his attempts, he cannot get them to work in concert to get out of bed: "I've got to get up, my train leaves at five!" (4).

Gregor's central preoccupation becomes evident: "His only concern had been to do everything in his power to let the family forget...the mercantile catastrophe that had plunged all of them into a state of utter hopelessness" (22). In the context of the family's economic pressures, Gregor had worked: "with particular zeal and risen almost overnight from petty clerk to salesman...[where] he had a quite different earning potential" (22). Kafka puts a spotlight on Gregor's role in rescuing the family's fortunes: "his sales commissions... were immediately transformed into cash that could be plunked down on the table at home, before the eyes of his astonished, delighted family" (22).

The threat of job loss, and by implication, the family's impecuniousness, is the sword of Damocles suspended over the heads of the family. In his transformation from human to insect, Kafka enunciates a series of losses. He sketches the social and economic world in which Gregor and his family are situated. He communicates the power relations at work in Gregor's life and household, which remain similar to today's. The occupational hierarchy is organized as a form of social control against which Gregor chafes: "As soon as I've saved up enough money to pay back what my parents owe him-another five or six years ought to be enough-I'll most definitely do that" (4).

Kafka limns a working world where the pressures of employment loom large for the family. Gregor bemoans his bondage to his employer: "If I didn't have to hold back for my parent's sake, I'd have given notice long ago-I'd have marched right up to him [his boss] and given him a piece of my mind" (4). He ponders: "What if he called in sick? 
But that would be mortifying and also suspicious, since Gregor had never once been ill in all his five years of service" (5). Gregor reflects on his certain absence from work: "No doubt his boss would come calling with the company doctor [who] would reproach Gregor's parents for their son's laziness" (5). Astoundingly, Gregor's boss does appear at his home, heightening the drama. Gregor remarks on the embarrassment of having his boss descend on his parent's home: "Did the general manager have to come in person, and was it necessary to demonstrate to the entire innocent family that the investigation of this suspicious matter could be entrusted only to the general manager's sharp intellect?" (8).

Depicting a world dominated by brutishness, Gregor refers to the overlords of industry to which he is indebted, lamenting: "Why oh why was Gregor condemned to serve in a firm where even the most negligible falling short was enough to arouse the greatest possible suspicion?" (5).

The lack of trust of employer in employee, the miserly attention that must be paid to time, to the very seconds ticking by, and the heavy yoke of the work contract, is embroidered into the story. The reader gains a sense that Gregor's very soul is at risk, a hallmark of Kafka's work, which reveals his concern with the human condition, including loss of human freedoms and dignity-highly relevant to those with HIV (Strauss 2016, 131):

Was every last one of the firm's employees a scoundrel, was there not a single loyal, devoted soul among them who would be driven mad by pangs of conscience should he fail to make the best possible use of even just a few morning hours for his employer's benefit? (8)

Gregor's boss shouts invectives through the closed door of Gregor's bedroom, demanding Gregor come out of his room and provide an explanation for his absence at work:

I must ask you for a clear and immediate explanation. I am astonished, utterly astonished. I've always known you as a calm, sensible person, and now it seems you've begun to permit yourself the most whimsical extravagances. (10)

Continuing his accusations, his boss shouts to Gregor through the door:

What has come over you? You barricade yourself in your room, you reply to queries only with yes and no, you cause your parents onerous, unnecessary worries, and you are neglecting - let me permit myself to note-your professional responsibilities in a truly unprecedented manner. (10)

Here, the manager is blaming Gregor for his illness or altered condition, just as those living with HIV are blamed for acquiring the virus (Earnshaw and Chaudoir 2009). By the end of Act I, Gregor's very identity as sole provider, his social and economic standing, and the family's income, is diminishing. Kafka communicates that while Gregor's physical form has already morphed from one form (man) to another (beast), this will quickly be matched by his social devaluation. Strikingly, Gregor's changed physical appearance has not made him frightful to himself, initially. Rather, he is merely curious (though this will change). Kafka casts his family-mother, father, and sister-into particular roles within the social hierarchy. These have the most influence on our protagonist's internalization of stigma, where stigma informs his sense of self, his anticipation of stigma (see Earnshaw and Chaudoir 2009; Pantelic, Sprague, and Stangl 2019), and his ultimate end. It is indeed in 'relation' with others that Kafka punctuates the effect of Gregor's conversion into an 
'other', i.e., separating those who are devalued by virtue of their condition, diagnosis, or other attribute, from the general population (Link and Phelan 2001, 370-371).

Gregor's mother is initially loving and protective, defending Gregor to his boss: "I'm so glad you paid us a visit, sir...we'd never have managed to persuade Gregor to open up... surely he isn't well, even though he denied it this morning" (9). Frau Samsa continues: "[He is] not well at all, take my word for it, sir. Why else would Gregor miss his train! The office is the only thing that boy ever thinks of" (9). Through the door of his bedroom, Gregor appeals to his boss for fairness and humane treatment, on behalf of his parents: "Sir! Do be gentle with my parents. The allegations you make are unfounded....I'll be back on the road in time for the eight o'clock train" (11). In response to Gregor's appeal, the manager is alerted to his very strange voice: the voice of a beast. His boss reacts with stunned disgust, asking the Samsa family: "Did you hear him speaking just now? That was an animal's voice" (11). Next, Gregor scuttles out of his bedroom, showing himself as a large arthropod for the first time.

\section{Act II. The boss makes haste}

The reaction of his boss and family to Gregor-cum-beetle is shock and horror. Their collective response further captures the unfolding social process of 'othering.' Kafka uses imagery in the form of gestures, actions and reactions, rather than dialogue, to relay the full potency of his boss's response to Gregor's change: "[the manager] pressed his hand to his open mouth, slowly retreating, as though being driven back by an invisible, steady force" (13).

\section{Theme 2. Stigma as an intersubjective process}

In the second theme, as Gregor's beetle body becomes fully visible to his family and boss, the intersubjectivity of stigma as a social process and construction also becomes manifest. Stern defines intersubjectivity as: "the capacity to share, know, understand, empathize with, feel, participate in, resonate with, and enter into the lived subjective experience of another" $(2013,78)$. Yang and colleagues elaborate the intersubjective nature of stigma:

much of stigma occurs in the inter-subjective space between people at the level of words, gestures, meanings, feelings, etc., during engagement with what matters most... By taking place both outside and inside a person, stigma is a social and subjective process. Thus, stigma can be viewed as interpersonal, or relational in nature. (2007, 524)

In a show of fear and disgust, Gregor's boss turns away, "his mouth contorted" (13). Kafka enunciates his rapid retreat:

to judge by the abrupt motion with which he [his boss] withdrew his foot from the living room... one might have supposed he'd just burned it...Having reached the vestibule...he stretched out his right hand, gesturing broadly in the direction of the stairs... as if some all but supernatural salvation awaited him there. (14-15)

Kafka then sharpens the contrast between Gregor as man and Gregor as insect, like a dimmer switch he is rotating to the brightest setting: Gregor catches sight of a framed photo of his former self. He is in his military garb, with his "carefree smile...he rested his 
hand on his dagger...[he] commanded respect for his bearing and his uniform" (14). In that moment, the photo serves to magnify the extent of Gregor's change and accompanying loss: from proud, esteemed soldier in control of his fate, to an insect that incites horror in his intimate circle. Gregor, hoping to salvage the situation, decides to reason with his boss. His job was at stake! He crawls in the manager's direction, out to the living room. The boss is now gripping the banister in fright: "The General Manager...looked back on the scene one last time... and leapt down several steps at once and vanished. And the cry of horror he gave as he fled resounded through the stairwell" (16). His mother's reaction enunciates the full magnitude of Gregor's change: "[She] leapt high up into the air...crying out to be rescued from the advancing beetle, 'Help me, for God's sake, help!'” (16). Here, too, readers gain the first real glimpse of Gregor's father. Herr Samsa tries to control the situation by seizing the manager's walking stick. He waves it at his son, ominously:

"[He] set about driving Gregor back into his room with a great stamping of feet, brandishing both newspaper and stick... making hissing noises" (16).

As Gregor is being pushed back into his bedroom, the undercurrent of violence meted out by father to son is palpable. Gregor tries to maneuver his many legs, but becomes injured:

Scraping his one flank raw and leaving ugly stains behind on the white door... he was wedged tight, unable to move... on one side, his little legs trembling in midair, while on the other they were crushed painfully beneath him. (17)

His father: "administered a powerful shove from behind...that sent him flying, bleeding profusely, into the far reaches of his room" (17). By the end of Act II, the gestures, words and interactions aimed at Gregor by his boss and family are grounded in fear and disgust in what he has now become, mirroring stigma experienced by those with HIV.

\section{Act III. Gregor becomes a patient}

Banished from the living room, Gregor will become a captive of his bedroom, and increasingly isolated from his family's companionship. Over time, in yet other hallmarks of HIV stigma, alienation and self-blame will dominate. Notably, Gregor's psychological state, which had remained quite hardy to this point, will deteriorate. Kafka further highlights Gregor's physical changes and the intersubjectivity of stigma, using the actions and reactions of sister Grete:

[Grete] opened his door and cast an anxious glance into his room. She didn't immediately spot him, but when she noticed him beneath the settee...the sight so alarmed her that, unable to control herself, she slammed the door. (19)

Initially caring and attentive, Grete marks the reduction in Gregor's status-from provider to dependent. She enters "as though she were entering the room of a gravely ill patient or even a stranger" (19). Similar to those with HIV whose family members require them to use separate utensils (Sprague et al. 2019), Grete avoids touching the food Gregor has eaten. She picked up the spilled milk: "not with her bare hands, to be sure, but with a rag" (19). Gregor observes and absorbs Grete's disgust: "[she] used a broom to sweep up not only the remains of his meal but also the food he hadn't even touched, as if these items too were no longer fit for consumption" (20). 
Gregor's view of himself as a burden intensifies. He wants to shield his family from suffering on his account. Gregor has been converted into a disgusting, 'other', excluded from the family. His very presence reduces the family's freedoms and mobility: "no one wanted to remain alone in the house with Gregor...[yet] the house could not be left unattended" (21). With Gregor unemployed, every family conversation centers on economic concerns. Gregor's shame at no longer occupying the provider role is pronounced: "Whenever the family...spoke of the necessity of someone earning money, Gregor would let go of the door and throw himself down upon the cool leather sofa beside it, burning with shame and sorrow" (24). Sadness preoccupies Gregor, precluding sleep: "He would lie there the entire long night, not sleeping for a moment, just scrabbling for hours against the leather" (24). Gregor's change is characterized as the greatest calamity of the family's lives:

The main thing keeping the family from moving to a new apartment was their complete sense of hopelessness...they had been struck with a misfortune, such as no one else in their entire circle...had ever experienced. (34)

$\mathrm{He}$ is increasingly anxious about the burden he has created for his loved ones: "If only he had been able to speak to his sister and thank her for all she was compelled to do for him, he would have found her ministrations easier to bear; as it was, he suffered beneath them" (24). Gregor has depressive thoughts: "[E]ating had soon ceased to give him even the slightest pleasure. Gregor now ate almost nothing at all" (36).

Grete starts changing, becoming less interested in Gregor's welfare. Instead, she belittles Gregor. Because Grete is horrified by his bug-like appearance, Gregor takes steps to hide himself, illustrating the anticipation of stigma (Earnshaw and Chaudoir 2009). Gregor begins to view himself with self-loathing, also revealing the internalization of stigma:

[Grete]...discovered him, motionless and propped upright as if for horrific effect... started in alarm and shut the door...Gregor naturally went and hid himself away beneath the settee.... he understood that his appearance was still unbearable to her. (25)

\section{Act IV. Gregor must disappear}

With good intentions, mother and sister decide to move the furniture out of Gregor's room so that he can roam freely, "crawling back and forth across the walls and ceiling" which prompts a crisis (26). By removing his belongings, Gregor is losing his connection to his old self-thus becoming even more alienated from his humanity. As he watches mother and sister in hiding, careful not to alarm his mother, Gregor reflects longingly on these symbols of his old self: "They were clearing out his room; taking... all that was dear to him...the desk at which he had written his homework assignments as a...pupil" (28). Gregor "burst out of hiding" in protest (28), but Gregor's mother was still not accustomed to his appearance, shrieking: "'Oh God, oh God!' and [she] fell back...her arms spread wide" (29). Gregor, again, blames himself: "his mother...was possibly on the brink of death, for which he himself was to blame" (29). Consumed by anxiety, Gregor is "tormented by his worries and self-reproach (30). Gregor tries to crawl after and comfort his mother but his father intervenes - again with violence: "his father had decided to bombard him...[hurling] one [apple]...[it] embedded itself in his back. Gregor...felt nailed to the spot and collapsed there" (31). Gregor is now mortally injured, his spirits at their lowest ebb: "The grievous wound Gregor had received...cost some of his mobility, probably for good... now he must hobble across the room like an old invalid" (32). 
After this, Gregor, feeling helpless, is plagued by self-blame. His wound aches. He falls into a deeper depression, seeming to deliberately starve himself, much like those with HIV who internalize stigma, punish themselves for their HIV serostatus (Earnshaw and Chaudoir 2009): "Gregor now ate almost nothing" (36). Becoming isolated from social contact, Gregor spends hours lying listlessly in the darkest corner of his room. He observes his own decline. He realizes his end is near: "I am wasting away...It seemed...as if it [his body] was gradually becoming weaker and weaker, and in the end would fade away altogether" (43).

The family argue over Gregor's fate. Grete insists that Gregor "must disappear"- that the family cannot bear the burden of Gregor, the patient, any longer. Gregor, too, decides he must disappear (43). Gregor's final reflections are of his love for his family and his desire to relieve their burden: "He thought back on his family with tenderness and love" (43).

\section{Act V. A new life begins}

The next morning, a maid finds Gregor unmoving in his room. She tries to tickle him with a broom to no avail: "she gawked in surprise...flung open the door of the bedroom and in a loud voice shouted... "Come have a look, it's gone and croaked-just lying there dead as a doornail!" (44). In turn, Herr and Frau Samsa "shot upright" (44): "[They] first had to recover from their shock. 'Dead?' Frau Samsa asked.... By way of proof, [the maid] pushed Gregor's corpse...to the side with her broom. Herr Samsa said, 'now we can thank God"” (44).

Kafka portrays the family's palpable release from the burden of managing Gregor as freedom and possibility, as if they've been sprung from prison. Immediately the family take a visit to the country: "all three...left the apartment together, something they had not done for months, and took the electric tram...to the open countryside" (46). Kafka uses the imagery of light to capture the bright future that awaits the family:

The car in which they sat all alone was entirely suffused with warm sunlight. Cozily leaning back in their seats, they discussed their future prospects, and on closer investigation it appeared that these prospects were...quite advantageous....The greatest would be their move to a smaller apartment; cheaper and more convenient than their current one, which had been picked out by Gregor (46).

As we come to the end, Kafka punctuates the transformation by focusing on new possibilities for Gregor's family in marked contrast with his death: "it seemed to them almost a confirmation of their new dreams and good intentions" (47).

\section{Discussion and implications for advancing understandings of HIV stigma in medical health education}

Kafka offers students of the health professions an alternative knowledge paradigm with which to engage HIV stigma. Rather than academic journal articles, the novella becomes the primary vehicle by which to engage stigma as a social construct and determinant of health. Kafka's economy of words, his humor and rapier-like writing style pull us into the drama from the start. His gift for sketching an entire social world in miniature ignites our 
imagination. He disarms our data-driven brains, compelling our curiosity, intuition and engaging our emotions (Mar et al. 2011). For readers who undertake the narrative journey alongside Gregor, Kafka reveals that stigmatization results in substantial losses-fully illuminating 'what is at stake' in theme one. The sociological-structural aspects of power and control that enable stigmatization to diminish one's economic and/or social position and identity are inextricably woven into the unfolding story. Employment becomes reduced or made impossible for Gregor: true for people living with HIV, globally (Sprague, Simon and Sprague 2011; UNAIDS 2020a). Gregor's social identity and role within the family deteriorates. Indeed, his family's social standing becomes reduced, relative to their neighbors and friends_-producing shame (Abassian 2007; Hutchinson and Dhairyawan 2017).

Via stigma as an intersubjective process in theme two, Gregor undergoes the same othering, blame and rejection that informs the lived experiences of many living with HIV (Orza et al. 2015; Sprague et al. 2019). In Kafka's narrative text-embracing gestures, actions and responses - readers come to comprehend how stigma is produced and reproduced in the power relationships and social roles that connect Gregor to his boss and family (Link and Phelan 2001; Parker and Aggleton 2003; Yang et al. 2007). Gregor's family labels him disgusting. They refer to him as a burden that must disappear. They seek to lock him away. Their responses inform Gregor's self-identity, leading to his internalization of stigma, depression and premature death (Pantelic, Sprague, and Stangl 2019). Readers see qualities of respect, fair and humane treatment replaced by scorn, ridicule, fear, gossip, and horror that Gregor's new state provoked in others. This characterization perfectly captures how those affected by the virus can be treated (NGO Delegation to the UNAIDS Programme Coordinating Board 2010). Gregor's travails of becoming an insect and the attendant process of reckoning with his 'discredited' self exemplify the social basis of ill health: how social factors like stigma shape the health status, opportunities, choices, behaviors and even outcomes of key populations living with HIV (WHO 2008; UNAIDS 2020a-b). As Gregor is stripped of his humanity, he loses, not only the love and companionship of his family, but his anticipated future: his dream of leaving his job and removing the shackles of his employment, of sending his sister to the conservatory. In this way, for people with stigmatized conditions, desired human capabilities may contract (Sen 1999). Kafka demonstrates that the effects of stigma can be viewed in terms of what matters most: human dignity, respect and esteem from others, love, friendship, health and essential freedoms-including the ability to construct a life one has reason to value (Sen 1999; Yang et al. 2007). To accompany Gregor on his metamorphosis-his alienation from his family, his depression and death-is to bear witness to the full social power of HIV stigma: to feel sadness, pathos, and distress, and to experience social exclusion and dehumanization (Kumagai and Wear 2014).

Metamorphosis also invites students to explore moral, ethical questions. The moral implications of stigma can be felt, observed, and debated by readers as they engage with the novella's cast of characters, who take on a caricature-like nature for effect, but remain believable, thus generating genuine relatability - even empathy for some. Kafka places Gregor's world onto the canvas, and through Gregor's circle, illuminates moral, social experience and how stigma can be shaped, circumscribed or extended by us all. Importantly, the text can ground readers in a conversation about alternative endings and realities. We could be Grete, the General Manager, Frau or Herr Samsa. A social construct, HIV stigma can be disrupted. Gregor's family could act differently. Just as families surprise individuals living with HIV-embracing them with love, and yes, empathy. By illustration, one participant in Mississippi anticipated HIV stigma from his family, which was not experienced, stating: 
It surprised me a whole lot because I thought I would get rejected. And I didn't... when I go to my family, they didn't care what I had [referring to HIV], what I went through, they were always there. (Sprague et al. 2019, 12)

Metamorphosis holds us in its grip. Through grappling with the events that unfurl over the story's course, students can debate the role of empathy, as the text prompts perspective-taking on the nature of our own values and professional ethics in a given situation. For example, via Grete's character, Kafka succeeds in breaking open the complex ethics of caregiving, while rendering the burden of care and the need for empathy universally relevant (Gordon, Benner, and Noddings 1996). Indeed, Grete begins as a loving sister, energetically electing the caretaking of her brother. As reflects reality, caregiving becomes labor-intensive and thankless, resulting in Grete's eventual detachment from her patient. Caregiver fatigue and burnout, as well as the need for 'sustainable empathy' for patients has remained urgent for frontline health professionals, globally, who are treating patients with COVID-19-many without sufficient personal protective equipment, resulting in avoidable infections and deaths (see Zaki 2020; Ranney, Griffeth, and Jha 2020). When a character and text can elicit such vicariousness in the reader, it forces reflection, as Wear and Nixon write: "while these fictional mirrors must tilt outward to reflect features external to the reader, they must eventually rotate back to the reader herself" $(1991,57)$. Nussbaum, too, states that it is in exactly this way that literature extends our life and moral experience, allowing us to fully "reflect and feel... what might otherwise be too distant for feeling" ("The Partially Examined Life" 2016, 1). She observes that this way of reading literature tests “our aspirations to live a good life through events outside of our control.' And, thus, literature 'becomes a way of moral learning, a way of training ourselves to recognize the important features in a moral situation" (1; see also Jones 1999). Such training is of high relevance for medical health students who will serve on the frontlines of both longstanding and emerging health threats.

\section{Conclusion}

Kafka's Metamorphosis can serve as a medium for exploring HIV stigma as a socialmedical problem that threatens 'what matters most' (Yang et al. 2007). The text facilitates exploration of HIV stigma as a social process, debates over empathic responses to patients who experience stigma (and intersecting stigmas) among students of the health professions, and social determinants that influence their patients' opportunities to be healthy. Utilizing Metamorphosis on its own would be insufficient to serve as an anti-stigma intervention targeting HIV stigma at the structural level. However, the novella could be paired with other methods, such as those identified earlier, and/or materials, to establish more durable responses in clinical settings. Indeed, employing Kafka has transformative possibilities. First, a pedagogical approach using Metamorphosis, rather than conventional academic journals, to produce a deeper understanding of the social basis of ill health and SDH that undergird stigma, is one predicated on valuing knowledge from the humanities to inform medical knowledge by emphasizing the sociological-relational aspects of stigma. This aligns with recommendations to integrate STEMM, arts and humanities in medical education. Second, Kafka has established an opening for students to enter into reflection and dialogue about stigma as embedded in social structures-clinical, family and community settings-its complex mechanisms and inner-workings, in ways that are multi-disciplinary 
and responsive to increasing health inequities for populations of color, sexual, gender minorities and other excluded groups. Here, literature enables readers to explore and discuss how the social and clinical worlds are intimately inter-connected, thus allowing students to reflect on moral, ethical concerns. This includes their professional identity and role within such structures: to perpetuate or change them. In this regard, Kafka offers an illustration of the very power of the medical health humanities to continue its social mission: to unfold such revelations in order for medical students, health professionals and researchers to fully grasp how sociological factors could enable, rather than disable, wellbeing - to ensure greater justice and equity in health and health care, particularly but not only, for people living with HIV (Vanderbilt University 2020; Berry, Jones and Lamb 2017).

Acknowledgements For comments that improved the manuscript, I thank the reviewers, editors Therese Jones and Kathy Pachucki, as well as Mary Gardill, Annalisa Lettinga and Laurie Zapalac. For deft and diligent research support, I thank Leena Maqsood.

\section{Endnote} ${ }^{1}$ In response to the limits of empathy, recent research has placed attention on when, how much and
which components of empathy allow humans to advance toward important goals. This includes improved
wellbeing and relationship satisfaction, and preventing negative outcomes associated with empathy, such
as health provider burnout, vicarious trauma, and the in-group bias that undergirds racism and social
exclusion. By implication, while incorporating institutional structures and practices to reduce stress and
burnout are recommended, scientists emphasize that determining which emotional regulation strategies
(e.g., meditation) predict precise outcomes offers an exciting direction for future research (see Weisz and
Cikara 2020).

\section{References}

Abbasian, Cyrus. 2007. "Medical Classics: The Metamorphosis.” British Medical Journal 335 (7609): 49.

Anand, Sudhir, Fabienne Peter, and Amartya Sen, eds. 2004. Public Health, Ethics, and Equity. Oxford: Oxford University Press.

Antony, James T. 2017. "Editorial: Metamorphosis: A Reason Why Many Chronic Schizophrenics Get Abandoned by Their Dear Ones." Indian Journal of Psychiatry 59 (1): 10-13.

Association of American Medical Colleges. 1998. "Report 1, Learning Objectives for Medical Student Education: Guidelines for Medical Schools.” Washington, DC: Association of American Medical Colleges.

Batey, D. Scott, Samantha Whitfield, Mazheruddin Mulla, Kristi L. Stringer, Modupeoluwa Durojaiye, Lisa McCormick, Bulent Turan, Laura Nyblade, Mirjam Colette-Kempf, and Janet M. Turan. 2016. "Adaptation and Implementation of an Intervention to Reduce HIV-Related Stigma Among Healthcare Workers in the United States: Piloting of the FRESH Workshop." AIDS Patient Care \& STDs 30 (11): 519-27.

Batt-Rawden, Samantha A., Margaret S. Chisolm, Blair Anton, and Tabor E. Flickinger. 2013. "Teaching Empathy to Medical Students: An Updated, Systematic Review." Academic Medicine 88 (8): 1171-7.

Berry, Sarah, Therese Jones, and Erin Lamb. 2017. "Editor's Introduction: Health Humanities: The Future of Pre-Health Education is Here.” Journal of Medical Humanities 38 (4): 353-60.

Bourdieu, Pierre. 1977. Outline of a Theory of Practice. Cambridge: Cambridge University Press.

Braveman, Paula, and Sofia Gruskin. 2003. "Defining Equity in Health." Journal of Epidemiology and Community Health 57 (4): 254-8.

Chen, Daniel C. R., Daniel S. Kirshenbaum, Jun Yan, Elaine Kirshenbaum, Robert H. Aseltine. 2012. "Characterizing Changes in Student Empathy throughout Medical School.” Medical Teacher 34 (4): 305-11.

Cohn, Susan Eggly, Richard D. Moore, and Mary Catherine Beach. 2016. "Clinician Empathy is Associated with Differences in Patient-clinician Communication Behaviors and Higher Medication Self-efficacy in HIV Care.” Patient Education \& Counseling 99 (2): 220-6.

Coles, Robert. 1995. The Mind's Fate: A Psychiatrist Looks at His Profession. Boston: Little, Brown and Company. 
Cooper, Vanessa, J. Clatworthy, E. Youssef, Carrie Llewellyn, Alec Miners, Mylene Lagarde, and Memory Sachikonye et al. 2016. "Which Aspects of Health Care are Most Valued by People Living with HIV in High-income Countries? A Systematic Review." BMC Health Services Research 16 (1): 677-92.

Crocker, Jennifer, Brenda Major, and C. Steele. 1998. "Social Stigma." In The Handbook of Social Psychology, edited by Daniel Todd Gilbert, Susan T. Fiske, and Gardner Lindzey, 504-53. New York: Oxford University Press.

Cronenberg, David. 2014. "The Beetle and the Fly." The Paris Review, January 17, 1-2.

Dang, Bich N., Robert A. Westbrook, Maria C. Rodriguez-Barradas, and Thomas P. Giordano. 2012. "Identifying Drivers of Overall Satisfaction in Patients Receiving HIV Primary Care: A Cross-sectional Study." PLoS One 7 (8): e42980.

Derksen, Frans, Jozien Bensing, and Antoine Lagro-Janssen A. 2013. "Effectiveness of Empathy in General Practice: A Systematic Review.” British Journal of General Practice 63 (606): e76-84.

Diderichsen, Finn, Timothy Evans, and Margaret Whitehead. 2001. "The Social Basis of Disparities in Health." In Challenging Inequities to Health: From Ethics to Action, edited by Timothy Evans, Margaret Whitehead, Finn Diderichsen, Abbas Bhuiya, and Meg Wirth, 12-23. Oxford: Oxford University Press.

Earnshaw, Valerie A., and Stephenie R. Chaudoir. 2009. "From Conceptualizing to Measuring HIV Stigma: A Review of HIV Stigma Mechanism Measures." AIDS and Behavior 13 (6): 1160-77.

Egede, Leonard E. and Rebekah J. Walker. 2020. "Structural Racism, Social Risk Factors, and Covid-19: A Dangerous Convergence for Black Americans.” New England Journal of Medicine 383 (12): e77.

Evans, Martyn. 2003. "Roles for Literature in Medical Education." Advances in Psychiatric Treatment 9 (5): 380-5.

Farmer, Paul. 2001. Infections and Inequalities: The Modern Plagues. Berkeley: University of California Press.

Flickinger, Tabor E., Somnath Saha, Debra Roter, P. Todd Korthuis, Victoria Sharp, Jonathan Cohn, Susan Eggly, Richard D. Moore, and Mary Catherine Beach. 2016. "Clinician Empathy is Associated with Differences in Patient-Clinician Communication Behaviors and Higher Medication Self-Efficacy in HIV Care." Patient Education \& Counseling 99 (2): 220-6.

Flood, David H., and Rhonda L. Soricelli. 2018. "The Metamorphosis and Related Works." In Health Humanities Reader, edited by Jones, Wear and Friedman, 26-35. New Brunswick: Rutgers University Press.

Foucault, Michel. 1995. Discipline and Punish: The Birth of the Prison. Translated by Alan Sheridan. New York: Random House.

Frain, Judy A. 2017. "Preparing Every Nurse to become an HIV Nurse." Nurse Educators Today 48: 129-33.

Garden, Rebecca Elizabeth. 2007. "The Problem of Empathy: Medicine and the Humanities.” New Literary History 38 (3): 551-67.

George, Gavin and Courtenay Sprague. 2011. "HIV Prevention in the World of Work in Sub-Saharan Africa: Research and Practice." African Journal of AIDS Research 10 (Supp 1): 291-300.

Geter, Angelica, Adrienne R. Herron, and Madeline Y. Sutton. 2018. "HIV-related Stigma by Healthcare Providers in the US: A Systematic Review." AIDS Patient Care and STDs 32 (10): 418-24.

Goffman, Erving. 1963. Stigma: Notes on the Management of a Spoiled Identity. New York: Simon \& Schuster.

Gordon, Suzanne, Patricia Benner, and Nel Noddings. 1996. Caregiving: Readings in Knowledge, Practice, Ethics, and Politics. Philadelphia: University of Pennsylvania Press.

Gruskin, Sofia, Edward J. Mills and Daniel Tarantola. 2007. "History, Principles, and Practice of Health and Human Rights." The Lancet 370 (9585): 449-55.

Hatzenbuehler, Mark L., Jo C. Phelan, and Bruce G. Link. 2013. "Stigma as a Fundamental Cause of Population Health Inequalities.” American Journal of Public Health 103 (5): 813-821.

Hay, Katherine, Lotus McDougal, Valerie Percival, Sarah Henry, Jeni Klugman, Haja Wurie, and Joanna Raven et al. 2019. "Disrupting Gender Norms in Health Systems: Making the Case for Change." The Lancet, 393 (10190): 2535- 49.

Hawkins, Anne Hunsaker, and Marilyn Chandler McEntyre. 2000. Teaching Literature and Medicine. New York: The Modern Language Association.

Hoffart, Shawn, George M. Ibrahim, Russell A. Lam, Evan P. Minty, Michelle Theam, and Jeffrey P. Schaefer. 2012. "Medical Students' Attitudes towards Treating Patients with HIV: A 12-year Follow-up Study." Medical Teacher 34:254.

Hojat, Mohammadreza, Joseph S. Gonnella, Thomas J. Nasca, Salvatore Mangione, Michael Vergare, and Michael Magee. 2002. "Physician Empathy: Definition, Components, Measurement, and Relationship to Gender and Specialty." American Journal of Psychiatry 159:1563-69. 
Hunter, Kathryn Montgomery. 1991. Doctors' Stories: The Narrative Structure of Medical Knowledge. Princeton: Princeton University Press.

Hutchinson, Phil, and Rageshri Dhairyawan. 2017. "Shame, Stigma, HIV: Philosophical Reflections." Medical Humanities 43 (4): 225-30.

Jones, Anne Hudson. 1999. "Narrative in Medical Ethics.” British Medical Journal 318:253-6.

Jones, Therese. 1994. Sharing the Delirium: Second Generation AIDS Plays and Performance. Portsmouth (NH): Heinemann/Methuen.

Jones, Therese, Delese Wear and Lester D. Friedman. 2018. Health Humanities Reader. New Brunswick (NJ): Rutgers University Press.

Kafka, Franz. 2016. The Metamorphosis. Translated by Susan Bernofsky. Edited by Mark Anderson. New York: WW Norton.

Kelm, Zak, James Womer, Jennifer K. Walter, and Chris Feudtner. 2014. "Interventions to Cultivate Physician Empathy: A Systematic Review.” BMC Medical Education 14: 1-11.

Kidd, David Comer, and Emanuele Castano. 2013. "Reading Literary Fiction Improves Theory of Mind." Science 342 (6156): 377-80.

Kleinman, Arthur. 2004. "Ethics and Experience: An Anthropological Approach to Health Equity." In Public Health, Ethics, and Equity, edited by Peter Anand, Fabienne Peter, and Amartya Sen, 269282. Oxford: Oxford University Press.

Kottow, Miguel, and Andrea Kottow. 2002. "Literary Narrative in Medical Practice." Medical Humanities 28 (1): 41-4.

Krishnasamy, Charmaine, Sik Yin Ong, May Eng Loo, and Jill Thistlethwaite. 2019. "How does Medical Education Affect Empathy and Compassion in Medical Students? A Meta-Ethnography: BEME Guide No. 57." Medical Teacher 41 (11): 1220-31.

Kumagai, Arno K. and Delese Wear. 2014. "Making Strange': A Role for the Humanities in Medical Education." Academic Medicine 89, (7): 973-7.

Li, Li, Zunyou Wu, Li-Jung Liang, Chunqing Lin, Jihui Guan, Manhong Jia, Keming Rou, and Zhihua Yan. 2013. "Reducing HIV-Related Stigma in Health Care Settings: A Randomized Controlled Trial in China." American Journal of Public Health 103 (2): 286-92.

Lin, Chunqing, Li Li, Dai Wan, Zunyou Wu, and Zhihua Wan. 2012. "Empathy and Avoidance in Treating Patients Living with HIV/AIDS (PLWHA) among Service Providers in China." AIDS Care 24 (11): 1341-8.

Link, Bruce G., and Jo C. Phelan. 2001. "Conceptualizing Stigma.” Annual Review of Sociology 27 (1): 363-85.

Logie, Carmen H., Ashley Lacombe-Duncan, Ying Wang, Angela Kaida, Tracey Conway, Kath Webster, and Alexandra de Pokomandy et al. 2018. "Pathways from HIV-related Stigma to Antiretroviral Therapy Measures in the HIV Care Cascade for Women Living with HIV in Canada." Journal of Acquired Immune Deficiency Syndromes 77 (2): 144-53.

Mar, Raymond A., Keith Oatley, Maja Djikic, and Justin Mullin. 2011. "Emotion and Narrative Fiction: Interactive Influences Before, During, and After Reading." Cognition and Emotion 25 (5): 818-33.

Marchalik, Daniel, and Ann Jurecic. 2015. "Novel Remedies.” Lancet 386 (10000): 1223.

McDonald, Paula, Katy Ashton, Rachel Barratt, Simon Doyle, Dorrie Imeson, Amos Meir, and GregoireRisser. 2015. "Clinical Realism: A New Literary Genre and a Potential Tool for Encouraging Empathy in Medical Students." BMC Medical Education 15 (112): 1-10.

Neumann, Melanie, Friedrich Edelhauser, Diethard Tauschel, Martin R. Fischer, Markus Wirtz, Christiane Woopen, Aviad Haramati, and Christian Scheffer. 2011. "Empathy Decline and its Reasons: A Systematic Review of Studies with Medical Students and Residents." Academic Medicine 86 (8): 996-1009.

NGO Delegation to the UNAIDS Programme Coordinating Board. "Stigma and Discrimination: Hindering Effective HIV Responses.” 2010. Accessed June 14, 2021. https://www.hivlaw.ch/wp-content/ uploads/sites/136/2020/05/2010_NGO_Report_Final_website.pdf

Nyblade, Laura, Rebecca J. Mbuya-Brown, Mangi J. Ezekiel, Nii A. Addo, Amon N. Sabasaba, Kyeremeh Atuahene, and Pfiraeli Kiwia et al. 2020. "A Total Facility Approach to Reducing HIV Stigma in Health Facilities: Implementation Process and Lessons Learned.” AIDS 34 (Suppl 1): S93-S102.

O'Connell, Gráinne. 2020. "Introduction: Framing 'Post-AIDS' and Global Health Discourses in 2015 and Beyond." Journal of Medical Humanities 41 (2): 89-94.

Okoro, Olihe and Folakemi Odedina. 2017. "HIV Treatment in African American Women-Care That Makes a Difference. Journal of Racial and Ethnic Health Disparities 4 (3): 376-84.

Orza, Luisa, Susan Bewley, Carmen H. Logie, Elizabeth Tyler Crone, Svetlana Moroz, Sophie Strachan, Marijo Vazquez, and Alice Welbourn. 2015. "How Does Living with HIV Impact on Women's Mental Health? Voices from a Global Survey.” Journal of the International AIDS Society 18 (Suppl 5): 1-9. 
Oxford English Dictionary. "Stigma." Accessed April 15, 2021. https://www.lexico.com/definition/stigma.

Pachankis, John E., Mark L. Hatzenbuehler, Katie Wang, Charles L. Burton, Forrest W. Crawford, Jo C. Phelan, and Bruce G. Link. 2018. "The Burden of Stigma on Health and Well-Being: A Taxonomy of Concealment, Course, Disruptiveness, Aesthetics, Origin, and Peril Across 93 Stigas." Personality and Social Psychology Bulletin 44 (4): 451-474.

Pantelic, Marija, Laurel Sprague, and Anne L. Stangl. 2019. "It's Not "All in Your Head": Critical Knowledge Gaps on Internalized HIV Stigma and a Call for Integrating Social and Structural Conceptualizations." BMC Infectious Diseases 19 (1): 210-8.

Parker, Richard, and Peter Aggleton. 2003. "HIV and AIDS-related Stigma and Discrimination: A Conceptual Framework and Implications for Action.” Social Science and Medicine 57 (1): 13-24.

Patel, Sundip, Alexis Pelletier-Bui, Stephanie Smith, Michael B. Roberts, Hope Kilgannon, Stephen Trzeciak, and Brian W. Roberts. 2019. "Curricula for Empathy and Compassion Training in Medical Education: A Systematic Review.” PLoS ONE 14 (8): e0221412.

Pentecost, Michelle, Berna Gerber, Megan Wainwright, and Thomas Cousins. 2018. "Critical Orientations for Humanising Health Sciences Education in South Africa." Medical Humanities 44 (4): 221-29.

Pohland, Vera. 2000. "Kafka's Corpus: Writing Tuberculosis and Being Literature.” In Teaching Literature and Medicine, edited by Anne Hunsaker Hawkins and Marilyn Chandler McEntyre, 233-42. New York: the Modern Language Association.

Power, Samantha. 2003. "The AIDS Rebel." The New Yorker, May 19.

Ranney, Megan L., Valerie Griffeth, and Ashish K. Jha. 2020. "Critical Supply Shortages-The Need for Ventilators and Personal Protective Equipment during the Covid-19 Pandemic." New England Journal of Medicine 382 (18): e41.

Rao, Deepa, Ahmed Elshafei, Minh Nguyen, Mark L. Hatzenbuehler, Sarah Frey and Vivian F. Go. 2019. "A Systematic Review of Multi-level Stigma Interventions: State of the Science and Future Directions." BMC Medicine 17 (41): 1-11.

Reid, Sandy. 2014. "The 'Medical Humanities' in Health Sciences Education in South Africa." South African Medical Journal 104 (2): 109-10.

Reif, Susan, Elena Wilson, Carolyn McAllaster, and Brian Pence. 2019. "The Relationship of HIV- related Stigma and Health Care Outcomes in the US Deep South." AIDS \& Behavior 23(3): 242-50.

Remien, Robert H., Michael J. Stirratt, Nadia Nguyen, Reuben N. Robbins, Andrea N. Pala, and Claude A. Mellins. 2019. "Mental Health and HIV/AIDS." AIDS 33 (9): 1411-20.

Rowe, Michael. 2002. "Metamorphosis: Defending the Human.” Literature \& Medicine 21 (2): 264-80.

Rubin, Elizabeth S., Jordan Rullo, Perry Tsai, Shannon Criniti, Joycelyn Elders, Jacqueline M. Thielen, and Sharon J. Parish. 2018. "Best Practices in North American Pre-Clinical Medical Education in Sexual History Taking: Consensus from the Summits in Medical Education in Sexual Health." The Journal of Sexual Medicine 15 (10): 1414-25.

Rueda, Sergio, Sanjana Mitra, Shiyi Chen, David Gogolishvili, Jason Globerman, Lori Chambers, Mike Wilson, Carmen H. Logie, Qiyun Shi, Sara Morassae, and Sean B. Rourke. 2016. "Examining the Associations between HIV-related Stigma and Health Outcomes in People Living with HIV/AIDS: A Series of Meta-analyses." BMJ Open 6 (7): 1-15.

Scott, Anne P. 2000. "The Relationship between the Arts and Medicine. Medical Humanities 26 (1): 3-8.

Sen, Amartya. 1999. Development as Freedom. New York: Random House.

Shapiro, Johanna, Lois L. Nixon, Stephen E. Wear, and David J. Doukas. 2015. "Medical Professionalism: What the Study of Literature Can Contribute to the Conversation." Philosophy, Ethics, and Humanities in Medicine 10 (10): 1-8.

Shilts, Randy. 1987. And The Band Played On. New York: St Martin's Press.

Sontag, Susan. 1989. AIDS and Its Metaphors. New York: Farrar, Strauss \& Giroux.

Solar, Orielle and Alec Irwin. 2010. "A Conceptual Framework for Action on the Social Determinants of Health. Social Determinants of Health Discussion Paper 2 (Policy and Practice). Geneva; World Health Organization. PDF file. Accessed July 29, 2021. https://www.who.int/sdhconference/resou rces/ConceptualframeworkforactiononSDH_eng.pdf.

South African National AIDS Council. 2017. South Africa's National Strategic Plan for HIV, TB and STIs 2017-2022. Pretoria: South African National AIDS Council. .https://sanac.org.za//wp-conte nt/uploads/2017/06/NSP_FullDocument_FINAL.pdf.

Sprague, Courtenay. 2018. Gender and HIV in South Africa: Advancing Women's Health and Capabilities. London: Palgrave Macmillan.

Sprague, Courtenay, Shelley M. Brown, Sara E. Simon, Lyndsey D. McMahan, Ira Kassiel and Deborah Konkle-Parker. 2019. "Towards Ending the US HIV Epidemic by 2030: Understanding Social Determinants of Health and HIV in Mississippi." Global Public Health 15 (1): 31-51. https://doi. org/10.1080/17441692.2019.1631366. 
Sprague, Courtenay and Sara E. Simon. 2014, "Understanding HIV Care Delays in the US South and the Role of the Social-Level in HIV Care Engagement/Retention: A Qualitative Study." International Journal for Equity in Health 13 (28): 1-14.

Sprague, Laurel, Sara E. Simon, and Courtenay Sprague. 2011. "Employment Discrimination and HIV Stigma: Survey Results from Civil Society Organizations and People Living with HIV in Africa." African Journal of AIDS Research 10 (Suppl 1): 311-24.

Stangl, Anne L., Jennifer K. Lloyd, Laura M. Brady, Claire E. Holland, and Stefan Baral. 2013. "A Systematic Review of Interventions to Reduce HIV-Related Stigma and Discrimination from 2002 to 2013: How Far Have We Come?" Journal of the International AIDS Society 16 (3) Suppl 2: 1-14.

Stern, Daniel N. 2013. "Intersubjectivity." In The American Psychiatric Publishing Textbook of Psychoanalysis, edited by Ethel S. Person, Arnold M. Cooper \& Glen O. Gabbard, 77-92. Arlington, TX: American Psychiatric Publishing.

Strauss, Nina Pelikan. 2016. “Transforming Franz Kafka’s Metamorphosis.” In The Metamorphosis, edited by Mark M. Anderson, 129-43. New York: WW Norton.

Taran, Shaurya, and Allan S. Detsky. 2018. "When Physicians Turn Into Patients-Becoming Kafka's Cockroach." Journal of the American Medical Association (JAMA) Internal Medicine 178 (6): 753-4.

Teding van Berkhout, Emily, and John M. Malouff. 2016. "The Efficacy of Empathy Training: A MetaAnalysis of Randomized Controlled Trials.” Journal of Counseling Psychology 63 (1): 32-41.

The Partially Examined Life. "Martha Nussbaum on Emotions, Ethics, and Literature." 2016. Accessed June 14, 2021. https://partiallyexaminedlife.com/2016/08/12/martha-nussbaum-on-emotions-ethics-and-literature/.

Thirioux, Berangere, Francois Birault, and Nematollah Jaafari. 2016. "Empathy is a Protective Factor of Burnout in Physicians: New Neuro-phenomenological Hypotheses regarding Empathy and Sympathy in Care Relationship." Front. Psychol. 7 (763): 1-11.

Tomso, Gregory. 2010."The Humanities and HIV/AIDS: Where Do We Go from Here?" Publications of the Modern Language Association of America 125 (2): 443-53.

Tsampiras, Carla. 2020. "Temporal Dissonance: South African Historians and the 'Post-AIDS' Dilemma." Journal of Medical Humanities 41 (2): 153-69.

Turan, Janet M., Melissa A. Elafros, Carmen H. Logie, Swagata Banik, Bulent Turan, Kaylee B. Crockett, Bernice Pescosolido, Sarah M. Murray. 2019. "Challenges and Opportunities in Examining and Addressing Intersectional Stigma and Health." BMC Medicine 17 (1): 7.

UNAIDS. 2020a. Evidence for Eliminating HIV-related Stigma and Discrimination. Accessed June 14, 2021. https://www.unaids.org/sites/default/files/media_asset/eliminating-discrimination-guida nce_en.pdf.

----.2020b. “UNAIDS Data 2020.” Accessed July 16, 2021. https://www.unaids.org/en/resources/docum ents/2020/unaids-data.

US Centers for Disease Control and Prevention. 2020a. Estimated HIV Incidence and Prevalence in the United States, 2014-2018. HIV Surveillance Supplemental Report 2020. 25, No. 1. .https://www.cdc. gov/hiv/pdf/library/reports/surveillance/cdc-hiv-surveillance-supplemental-report-vol-25-1.pdf.

----.2020b. Overview 2020 HIV: USA at a Glance, HIV Care. https://www.cdc.gov/hiv/images/statistics/ overview/2020/hiv-us-ataglance-2020-hiv-care-download.png.

----. 2016. "Half of Black Gay Men and a Quarter of Latino Gay Men Projected to be Diagnosed within their Lifetime." . https://www.cdc.gov/nchhstp/newsroom/2016/croi-press-release-risk.html.

US National Academies of Sciences, Engineering, and Medicine. 2018. "The Integration of the Humanities and Arts with Sciences, Engineering, and Medicine in Higher Education: Branches from the Same Tree." Washington, DC: The National Academies Press.

Vanderbilt University. 2020. "Call for Papers: The Politics of Health 2020: International Health Humanities Consortium Conference.” . https://petrieflom.law.harvard.edu/resources/opportunity/call-for-papersthe-politics-of-health-2020-international-health-humanities.

Walker, Liz. 2020. "Problematising the Discourse of Post-AIDS." Journal of Medical Humanities 41: 95-105.

Wear, Delese, and Lois LaCivita Nixon. 1991. "The Fictional World: What Literature Says to Health Professionals." Journal of Medical Humanities 12 (2): 55-64.

Weiss, Rachel, Eric Vittinghoff, Margaret C. Fang, Jenica EW Cimino, Kristen A. Chasteen, Robert M. Arnold, Andrew D. Auerbach, and Wendy G. Anderson. 2017. "Associations of Physician Empathy with Patient Anxiety and Ratings of Communication in Hospital Admission Encounters." Journal of Hospital Medicine 12 (10): 805-810.

Weisz, Erika, and Mina Cikara. 2020. "Strategic Regulation of Empathy." Trends in Cognitive Sciences 25 (3): 213-27. 
Whitehead, Anne, Angela Woods, Sarah Atkinson, Jane Macnaughton, and Jennifer Richards. 2016. The Edinburgh Companion to the Critical Medical Humanities. Edinburgh: Edinburgh University Press.

World Economic Forum. 2017. The Global Risks Report $201712^{\text {th }}$ Edition. Accessed June 14, 2021. http:// www3.weforum.org/docs/GRR17_Report_web.pdf.

World Health Organization. 2008. Closing the Gap in a Generation: Health Equity through Action on the Social Determinants of Health Final Report Executive Summary (2008). Accessed July 29, 2021. https://www.who.int/social_determinants/final_report/csdh_finalreport_2008.pdf.

----. 2013. The Helsinki Statement on Health in All Policies 2013. Accessed June 23, 2021. https://www. who.int/healthpromotion/conferences/8gchp/8gchp_helsinki_statement.pdf.

Yang, Kuang-Tao, and Jen-Hung Yang. 2013. "A Study of the Effect of a Visual Arts-Based Program on the Scores of Jefferson Scale for Physician Empathy.” BMC Medical Education 13 (142).

Yang, Lawrence H., Arthur Kleinman, Bruce G. Link, Jo C. Phelan, Sing Lee, and Byron Good. 2007."Culture and Stigma: Adding Moral Experience to Stigma Theory." Social Science \& Medicine 64 (7): $1524-1535$.

Zaki, Jamil. 2020. "The Caregiver's Dilemma: In Search of Sustainable Medical Empathy." Lancet 396 (10249): 458-59.

Publisher's Note Springer Nature remains neutral with regard to jurisdictional claims in published maps and institutional affiliations. 